Vol. 7, Nomor 1, April 2013

\title{
Pelaksanaan Terapi Wicara dan Terapi Sensori Integrasi pada Anak Terlambat Bicara
}

\author{
Sunanik \\ Sekolah Tinggi Agama Islam Negeri Samarinda \\ Email: sunanik276@gmail.com
}

\begin{abstract}
The background of this research is the idea that a speech and language disorder is the causes of developmental disorders that are commonly found in children. Such disorder increases rapidly. Some reports put a number of speech and language disorder in the ranges from 5-10\% in school children. This makes the speech delay as the most common disorder in childhood, so that quick treatment and appropriate therapy are highly needed for children with speech delay. The therapies made are speech therapy and sensory integration. The implementation of speech therapy and sensory integration should be given to children as early as possible. Speech therapy and sensory integration in children with speech delay have important role in determining the child's language development and motor skills. Inclusive education is education that puts all learners with special needs in the regular school day. In this kind of education, teachers have full responsibility for learners with special needs.
\end{abstract}

Keywords: speech therapy, sensory integration therapy.

\begin{abstract}
Abstrak
Penelitian ini dilatarbelakangi bahwasanya gangguan bicara dan bahasa adalah salah satu penyebab gangguan perkembangan yang paling sering ditemukan pada anak. Gangguan ini semakin hari tampak semakin meningkat pesat. Beberapa laporan menyebutkan angka kejadian gangguan bicara dan bahasa berkisar 5$10 \%$ pada anak sekolah. Hal ini menjadikan keterlambatan bicara adalah kelainan yang paling umum terjadi pada masa anak-anak, sehingga diperlukan penanganan yang cepat dan terapi yang sesuai dengan kebutuhan dan tentunya yang terbaik bagi anak-anak terlambat bicara. Di antaranya adalah terapi wicara dan sensori integrasi. Pelaksanaan Terapi wicara dan sensori integrasi hendaknya diberikan kepada anak sedini mungkin. Terapi wicara dan sensori integrasi pada anak terlambat bicara mempunyai peranan penting dan menentukan perkembangan bahasa dan motorik anak selanjutnya.
\end{abstract}

Kata kunci: terapi wicara, terapi integrasi sensorik. 


\section{A. Latar Belakang Masalah}

Pendidikan adalah bimbingan atau pimpinan secara sadar oleh penduduk terhadap perkembangan jasmani dan rohani anak menuju terbentuknya kepribadian. ${ }^{1}$ Pendidikan adalah hak asasi yang paling mendasar bagi setiap manusia, tidak terkecuali bagi anak luar biasa atau anak berkebutuhan khusus. Dalam Undang-Undang Dasar 1945 pasal 31 ayat 2 disebutkan bahwa "tiap-tiap warga Negara berhak mendapatkan pengajaran", dan ditambahkan dalam Undang-Undang nomor 20 tahun 2003 tentang Sistem Pendidikan Nasional pasal 5 ayat 2 bahwa "Negara yang memiliki kelainan fisik, emosional, mental, intelektual, atau sosial berhak memperoleh pendidikan khusus". ${ }^{2}$ Dengan demikian berarti anak-anak yang dengan kebutuhan khusus seperti, tunanetra, tunarungu, tunagrahita, tunadaksa, tunalaras dan anak-anak berkesulitan belajar juga memiliki kesempatan yang sama untuk mendapatkan pendidikan.

Pengakuan atas hak pendidikan bagi setiap warga negara, juga diperkuat dalam berbagai deklarasi internasional. Pada tahun 1948, Deklarasi Hak Asasi Manusia mengeluarkan pernyataan bahwa pendidikan adalah hak asasi manusia yang paling dasar (basic human right). Deklarasi tersebut diperkuat lagi dalam Convention on The Rights of The Child yang diselenggarakan oleh PBB (1989) dan telah diratifikasi oleh pemerintah Indonesia. Selanjutnya dalam The World Convention on Education for All di Jomtien, Thailand (1990), yang kemudian dikenal dengan The Jomtien Declaration, antara lain juga ditegaskan perlunya memperluas akses pendidikan kepada semua anak, remaja, dan dewasa, juga memberikan kesempatan yang sama kepada anak-anak perempuan. ${ }^{3}$ Deklarasi Jomtien ini diperkuat lagi dalam The Salamanca Statement and Framework for Action on Special Needs Education tahun 1994 yang secara lebih tegas menuntut agar pendidikan bagi anak berkebutuhan khusus bersifat inklusi, sehingga sistem pen-

${ }^{1}$ Ahmad D. Marimba, Pengantar Filsafat Pendidikan Islam (Bandung: Al-Bayan, 1996), hlm. 19.

${ }^{2}$ Undang-Undang No. 20 tahun 2003, tentang Sistem Pendidikan Nasional dan Penjelasannya (Jakarta: Depdiknas)

${ }^{3}$ Sue Stubbs, Pendidikan Inklusif, Ketika Hanya Ada Sedikit Sumber, terj. Susi Septaviana R, Didi Tarsidi (ed.). (Oslo, Norway: The Alliance, 2002), hlm. 16. 
didikan yang memisahkan individu dan komunitasnya merupakan pelanggaran hak asasi manusia. ${ }^{4}$

Pendidikan inklusi didasarkan atas pandangan bahwa semua anak berhak untuk masuk ke sekolah reguler. Tugas sekolah adalah menyediakan kebutuhan semua anak dalam komunitasnya, apapun derajat kemampuan dan ketidakmampuannya. Dalam pendidikan inklusi semua perbedaan dihargai, termasuk perbedaan ras, etnik, maupun latar belakang sosial dan budaya. ${ }^{5}$ Menurut Yuliani:

"Pendidikan inklusi sebagai pendidikan yang menempatkan semua peserta didik berkebutuhan khusus dalam sekolah reguler sepanjang hari. Dalam pendidikan seperti ini, guru memiliki tanggung jawab penuh terhadap peserta didik berkebutuhan khusus tersebut". 6

Pengertian ini memberikan pemahaman bahwa pendidikan inklusi menyamakan anak berkebutuhan khusus dengan anak normal lainnya. Sehingga guru memiliki tanggung jawab penuh terhadap proses pelaksanaan pembelajaran di kelas. Untuk itu guru harus memiliki kemampuan dalam menghadapi banyaknya perbedaan peserta didik. Hal ini menyebabkan adanya penyesuaian-penyesuaian yang harus dilakukan oleh guru dalam proses pembelajaran. ${ }^{7}$

Gangguan bicara dan bahasa adalah salah satu penyebab gangguan perkembangan yang paling sering ditemukan pada anak. Keterlambatan bicara adalah keluhan utama yang sering dicemaskan dan dikeluhkan orang tua kepada dokter. ${ }^{8}$ Gangguan ini semakin hari tampak semakin meningkat pesat. Beberapa laporan menyebutkan angka kejadian gangguan bicara dan bahasa berkisar $5-10 \%$ pada anak sekolah. ${ }^{9}$ Anak yang mengalami keterlambatan

\footnotetext{
${ }^{4}$ Sue Stubbs, Pendidikan Inklusif ..., hlm. 17.

5 Yuliani Nurani Sujono, Konsep Dasar Pendidikan Anak Usia Dini, (Jakarta: Indeks, 2009), hlm. 169.

${ }^{6}$ Daniel P. HAllahan dkk., Exceptional Learners: An Introduction to Special Education (Boston: Pearson Education Inc., 2009), cet. ke-10, hlm. 53.

7 Gavin Reid, Dyslexia and Inclusion; Classroom Approaches for Assesment, Teaching and Learning (London: David Fulton Publisher, 2005), hlm. 88.

8 IG. Ranuh, Tumbuh Kembang Anak dan Remaja, (Jakarta: Sagung Seto, 2002), hlm. 91.

9 Judarwanto, Keterlambatan bicara - Speech delay. www.keterlambatan-bicara.blogspot.com. 2008, Diakses pada tanggal 14 maret 2012 jam 10.45 WIB.
} 
bicara dan bahasa beresiko mengalami kesulitan belajar, kesulitan membaca dan menulis dan akan menyebabkan pencapaian akademik yang kurang secara menyeluruh, hal ini dapat berlanjut sampai usia dewasa muda. Selanjutnya orang dewasa dengan pencapaian akademik yang rendah akibat keterlambatan bicara dan bahasa, akan mengalami masalah perilaku dan penyesuaian psikososial. ${ }^{10}$

Melihat sedemikian besar dampak yang timbul akibat keterlambatan bahasa pada anak usia pra sekolah maka sangatlah penting untuk mengoptimalkan proses perkembangan bahasa pada periode ini. Deteksi dini keterlambatan dan gangguan bicara usia prasekolah adalah tindakan yang terpenting untuk menilai tingkat perkembangan bahasa anak, sehingga dapat meminimalkan kesulitan dalam proses belajar anak tersebut saat memasuki usia sekolah. Beberapa ahli menyimpulkan perkembangan bicara dan bahasa dapat dipakai sebagai indikator perkembangan anak secara keseluruhan, termasuk kemampuan kognisi dan kesuksesan dalam proses belajar di sekolah. ${ }^{11}$ Hasil studi longitudinal menunjukkan bahwa keterlambatan perkembangan bahasa berkaitan dengan intelegensi dan membaca di kemudian hari. ${ }^{12}$

Penanganan keterlambatan bicara memerlukan waktu yang agak lama serta kerja sama yang baik dari orangtua. Beberapa anak tidak memperoleh penanganan dengan baik sampai masalah perkembangan itu menjadi sesuatu yang tidak dapat ditangani atau berdampak secara signifikan terhadap hal-hal lain. ${ }^{13}$ Keterlambatan bicara sering disertai gangguan lainnya sesuai dengan penyakitnya seperti hiperaktif, tingkah laku yang aneh, sulit untuk diajak kerja sama, maka penanganannya harus dimulai dengan memperbaiki perilakunya. Setelah itu baru bisa diberikan terapi yang mendukung seperti terapi wicara, terapi okupasi, terapi sensori integrasi dll. Penanganannya memerlukan kerja sama dari

${ }^{10}$ RE. Owens, Language Development an Introduction, 5th edition. (New York:Allyn and Bacon; 2001)

11 Hill J Smith C, Language Development and Disorders of Communication and Oral Motor Function, In : Molnar GE, Alexander MA, editors, Pediatric Rehabilitation, (Philadelphia: Hanley and Belfus;1999), hlm. 57-79.

${ }^{12}$ Majnemer A, dkk., Screening for developmental delay in the setting of a community pediatr clinic: A Prospective assessment of parent-Report questionnaires. (Pediatrics 2006), hlm. 118.

${ }^{13}$ Majnemer A, dkk., Screening for ..., hlm. 118. 
berbagai ahli seperti fisioterapis, ahli terapi okupasi selain tentunya ahli terapi wicara. ${ }^{14}$

Dalam penanganan anak berkebutuhan khusus dilakukan terapi wicara dan sensori integrasi. Terapi wicara di gunakan untuk menangani anak dengan gangguan komunikasi hal ini sering dideteksi terlambat bicara. Untuk itu diperlukan terapi wicara dengan melatih wicara anak agar anak dapat berkomunikasi dengan masyarakat. Terapi ini untuk melatih anak terampil mempergunakan sistem encoding berupa kemampuan mempergunakan organ untuk bicara, menggerakkan lengan tangan dan tubuh yang lain, serta ekspresi wajah. Sedangkan dalam pengetahuan anak diharapkan mampu mengerti tentang cara mengucapkan seluruh bunyi bahasa dengan benar, mengevaluasi bicaranya sendiri berdasarkan pengamatan visual, auditori, dan kinestetis. Sementara untuk sikap diharapkan anak berperilaku baik terhadap orang lain sehingga emosi anak berkembang seimbang.

Terapi sensory integrasi adalah proses neurological yang mengorganisasikan sensori dari tubuh seseorang dan dari lingkungan. Pengorganisasian ini akan memungkinkan tubuh merespon lingkungannya secara efektif. Terapi ini juga mengintegrasikan informasi sensori yang akan digunakan melalui sensori (sentuhan, kesadaran, gerakan tubuh, keseimbangan dan gravitasinya, pengecapan, penglihatan dan pendengaran), memori dan knowledge. Semua itu disimpan di otak untuk menghasilkan respon bermakna.

\section{B. Perkembangan Bahasa Anak}

Komunikasi berarti suatu pertukaran pikiran dan perasaan. Pertukaran tersebut dapat dilaksanakan dengan setiap bentuk bahasa seperti: isyarat, ungkapan emosional, bicara, atau bahasa tulisan, tetapi komunikasi yang paling umum dan paling efektif dilakukan dengan bicara. ${ }^{15}$ Menurut Soetjiningsih:

"Berbahasa merupakan proses yang menyeluruh dan tidak terjadi begitu saja. Setiap individu berkomunikasi lewat bahasa memerlukan suatu proses yang untuk berkomunikasi selalu menjadi perta-

${ }^{14}$ Oka Lely, Jika anak terlambat bicara. www.balipost.com. Diakses pada tanggal 14 maret 2012, jam 11.20 WIB.

${ }^{15}$ Elizabeth B. Hurlock, Perkembangan Anak, edisi keenam, (McGrawHill: Erlangga, 2008), hlm 176-177. 
nyaan yang menarik untuk dibahas sehingga memunculkan banyak teori tentang pemerolehan bahasa". ${ }^{16}$

Kemampuan berbahasa dan bicara merupakan alat utama untuk berkomunikasi bagi kita sebagai manusia. Ketika salah satu dari instrumen atau organ bicara terganggu, maka komunikasi seseorang akan terganggu pula. Semakin berat gangguan organorgan bicara itu, maka semakin berat pula gangguan komunikasi yang dialami oleh seseorang. ${ }^{17}$

Perkembangan bahasa mengikuti suatu urutan yang dapat diprediksi secara umum meskipun terdapat keberagaman yang satu dengan yang lainnya, dengan maksud untuk mengembangkan kemampuan anak dalam berkomunikasi. Perkembangan bahasa anak mayoritas dimulai dengan menangis. Anak berusahan mengekspresikan responnya terhadap berbagai stimulan. Sesaat kemudian, anak mulai memeram (cooing), yakni secara berulang melafalkan bunyi yang tidak ada artinya. Kemudian, anak mulai belajar kalimat dengan satu kata, ${ }^{18}$ seperti "mimik" yang artinya ia haus minta minum. Berikut tabel perkembangan perilaku anak normal:

\begin{tabular}{|c|c|c|}
\hline Umur & Kemampuan Motorik & Kemampuan Wicara \\
\hline Lahir & Fiksasi pandangan & Bereaksi terhadap suara \\
\hline 5 Minggu & Mengikuti benda di tengah garis & Tersenyum sosial \\
\hline 2 Bulan & Telapak tangan terbuka & Guuu...Guuu.. \\
\hline 3 Bulan & Menyatukan kedua tangan & $\begin{array}{l}\text { Orientasi terhadap suara } \\
\text { A guuu.., a guuu... }\end{array}$ \\
\hline 4 Bulan & Mengetahui adanya benda kecil & Mengoceh \\
\hline 5 Bulan & $\begin{array}{l}\text { Memindahkan benda antara } \\
\text { kedua tangan }\end{array}$ & $\begin{array}{l}\text { Orientasi kepada suara } \\
\text { bek fase I } \\
\text { Mengoceh }\end{array}$ \\
\hline 6 Bulan & Meraih unilateral & $\begin{array}{l}\text { Mengoceh } \\
\text { Dadadada...(mengguma } \\
\text { m) }\end{array}$ \\
\hline 7 Bulan & Memeriksa benda & $\begin{array}{l}\text { Menoleh kepada suara } \\
\text { bel fase II }\end{array}$ \\
\hline 8 Bulan & Memeriksa benda & $\begin{array}{l}\text { Mengerti perintah:"tidak } \\
\text { boleh!"” } \\
\text { Da-da..tanpa arti }\end{array}$ \\
\hline
\end{tabular}

16 Soetjiningsih, Perkembangan Anak dan Permasalahannya. Jakarta: Ikatan Dokter Anak Indonesia, (Jakarta: Sagung Seto; 2002), hlm. 9.

17 Abdul Hadis, Pendidikan Anak Berkebutuhan Khusus-Autistik, (Bandung: Alfaneta, 2006), hlm. 16-17.

18 Mansur, Pendidikan Anak Usia Dini Dalam Islam (Yogyakarta: Pustaka Pelajar, 2009), hlm. 35. 


\begin{tabular}{|c|c|c|}
\hline & & Ma-ma...tanpa arti \\
\hline 9 Bulan & $\begin{array}{l}\text { Pincet grasp premature } \\
\text { Melemparkan benda }\end{array}$ & Dada \\
\hline 10 Bulan & Membuka penutup mainan & $\begin{array}{l}\text { Menoleh kepada suara } \\
\text { bel fase III }\end{array}$ \\
\hline 11 Bulan & $\begin{array}{l}\text { Pincet grasp dengan jari } \\
\text { Meletakkan kubus di bawah } \\
\text { gelas }\end{array}$ & $\begin{array}{l}\text { Mengerti perintah } \\
\text { ditambah mimik }\end{array}$ \\
\hline 12 Bulan & $\begin{array}{l}\text { Melepaskan benda dengan } \\
\text { sengaja }\end{array}$ & $\begin{array}{l}\text { Mama dan kata pertama } \\
\text { selain mama }\end{array}$ \\
\hline 13 Bulan & Mencoret & Kata kedua \\
\hline 14 Bulan & $\begin{array}{l}\text { Memasukkan biji ke dalam } \\
\text { botol }\end{array}$ & Kata ketiga \\
\hline 15 Bulan & $\begin{array}{l}\text { Minum dari gelas sendiri } \\
\text { Menggunakan sendok }\end{array}$ & $\begin{array}{l}\text { Mengerti perintah tanpa } \\
\text { mimik }\end{array}$ \\
\hline 16 Bulan & Melepaskan biji dengan meniru & 4-6 kata \\
\hline 17 Bulan & $\begin{array}{l}\text { Meniru membuat garis } \\
\text { Menyusun dua kubus }\end{array}$ & $\begin{array}{l}\text { Menunjuk lima bagian } \\
\text { badan yang disebutkan }\end{array}$ \\
\hline 18 Bulan & $\begin{array}{l}\text { Melepaskan biji spontan } \\
\text { Menyusun tiga kubus }\end{array}$ & $7-20$ kata \\
\hline 21 Bulan & Membuat garis secara spontan & $\begin{array}{l}\text { Kalimat pendek yang } \\
\text { terdiri atas dua kata }\end{array}$ \\
\hline 24 Bulan & $\begin{array}{l}\text { Kereta api dengan empat kubus } \\
\text { Membuka baju sendiri }\end{array}$ & 50 kata \\
\hline $\begin{array}{l}25-27 \\
\text { Bulan }\end{array}$ & Membuat garis datar dan tegak & $\begin{array}{l}\text { Kalimat pendek yang } \\
\text { terdiri atas dua kata }\end{array}$ \\
\hline 30 Bulan & $\begin{array}{l}\text { Kereta api dengan cerobong } \\
\text { asap } \\
\text { Menirukan membuat lingkaran }\end{array}$ & $\begin{array}{l}250 \text { kata } \\
\text { Kalimat terdiri dari tiga } \\
\text { kata }\end{array}$ \\
\hline 3 Tahun & $\begin{array}{l}\text { Membuat lingkaran spontan } \\
\text { Membuat jembatan dari tiga } \\
\text { kubus } \\
\text { Membuka kancing }\end{array}$ & $\begin{array}{l}\text { Kalimat terdiri dari 4-5 } \\
\text { kata }\end{array}$ \\
\hline 4 Tahun & $\begin{array}{l}\text { Membuat pintu gerbang dari } \\
\text { lima kubus } \\
\text { Memasang kancing }\end{array}$ & Bercerita \\
\hline 5 Tahun & Meningkatkan tali sepatu & $\begin{array}{l}\text { Menanyakan arti suatu } \\
\text { kata }\end{array}$ \\
\hline 6 Tahun & $\begin{array}{l}\text { Membuat tangga dan dinding } \\
\text { beberapa kubus tanpa contoh }\end{array}$ & Menghitung sampai 20 \\
\hline
\end{tabular}

\section{Tabel 1}

Perkembangan Perilaku anak Normal ${ }^{19}$

19 Y. Handoyo, Autisme pada anak: Menyiapkan Anak Autis untuk Mandiri dan Masuk Sekolah Reguler dengan Metode ABA Basic, (Jakarta: Bhuana Ilmu Populer, 2009), hlm 255-207. 
Klasifikasi gangguan komunikasi yang menjadi bidang garap terapi wicara tersebut adalah sebagai berikut:

1. Gangguan Wicara (artikulasi). Salah satu jenis gangguan perilaku komunikasi oleh karena satu atau beberapa sebab yang berhubungan dengan fungsi pengamatan (sensasi dan persepsi), fungsi neuromuskuler, kondisi organ bicara, atau adanya pengaruh dari lingkungan mengalami kesulitan untuk menggunakan bunyi-bunyi bahasa dengan benar. Dalam hal ini kesalahan terletak pada titik temu/tumpu artikulasi (point of articulation) atau pada cara memproduksi bunyi bahasa (manner of articulation). Kesulitan bicara biasanya ditandai adanya Subtitusi (penggantian), Omisi (penghilangan), Distorsi (tidak jelas) dan Adisi (penambahan). Gangguan perkembangan artikulasi meliputi kegagalan mengucapkan satu huruf sampai beberapa huruf, sering terjadi penghilangan atau penggantian bunyi huruf tersebut sehingga menimbulkan kesan cara bicaranya seperti anak kecil. Selain itu juga dapat berupa gangguan dalam pitch, volume atau kualitas suara. ${ }^{20}$

2. Gangguan Bahasa. Salah satu jenis gangguan perilaku komunikasi dimana penderita gangguan bahasa mengalami hambatan atau kesulitan proses simbolisasi (coding) dan penggunaan kaidah linguistik yang dipergunakan oleh lingkungannya, sehingga penderita mengalami hambatan dalam perkembangan, hambatan kemampuan reseptif, hambatan kemampuan ekspresif. Gangguan bahasa ini dapat terjadi akibat adanya lesi pada pusat-pusat bahasa di korteks serebri. ${ }^{21}$

3. Gangguan Suara. Salah satu jenis komunikasi yang ditandai dengan adanya gangguan proses produksi suara (fonasi) ini biasanya terjadi akibat adanya sebab-sebab organik maupun fungsional yang mempengaruhi fungsi laring pada waktu fonasi. Gangguan dalam proses produksi suara ini dapat ditandai dengan adanya gangguan pada aspek-aspek suara, meliputi : kenyaringan (loudness), nada (pitch), dan kualitas (quality). Gangguan suara secara garis besar dibedakan menjadi 2 (dua) yaitu disfonia dan afonia: a) Disfonia adalah suatu kondisi gangguan komunikasi dalam bentuk penyim-

${ }^{20}$ Y. Handoyo, Autisme pada ..., hlm 255-207.

${ }^{21}$ Mustwkupang, Terapi Wicara, http://mustwkupang.blogspot.com/2012/01/terapi-wicara.html, diakses tanggal 09 Mei 2012, jam 10.21 WIB. 
pangan atau kurang sempurnanya di dalam produksi suara yang disebabkan oleh faktor organik maupun fungsional. Kondisi ini meliputi: (1) Gangguan nada, (2) Gangguan dan (3) Gangguan kualitas. b) Afonia adalah suatu kondisi gangguan komunikasi yang disebabkan oleh kehilangan sumber suara atau mengalami kegagalan sama sekali di dalam memproduksi suara.

4. Gangguan Irama/Kelancaran, salah satu jenis gangguan perilaku komunikasi ditandai dengan adanya pengulangan (repetition) bunyi atau suku kata dan perpanjangan (prolongation) serta blocking pada saat berbicara. Adanya pengulangan, perpanjangan dan blocking pada saat berbicara menyebabkan penderita tidak mampu berbicara dengan lancar. Pada umumnya terjadi sehubungan dengan adanya ganggguan psikososial atau karena sebab-sebab lain yang mengganggu/ mempengaruhi fungsi neuromotor organ bicara. Gangguan Irama/Kelancaran dibedakan menjadi 3 yaitu: 1) gagap (stuttering), ${ }^{22}$ 2) cluttering, 3) latah.

5. Gangguan Menelan (disfagia), Disfagia ini merupakan kesulitan menelan yang terbagi menjadi 3 (tiga) fase yaitu fase oral, phase pharyngeal dan phase eshopageal yang disebabkan kondisi patologis, psikogenik dan neurologis. ${ }^{23}$ Penyebab gangguan perkembangan bahasa sangat banyak dan luas, semua gangguan mulai dari proses pendengaran, penerusan impuls ke otak, otak, otot atau organ pembuat suara.

Adapun beberapa penyebab gangguan atau keterlambatan bicara adalah gangguan pendengaran, kelainan organ bicara, retardasi mental, kelainan genetik atau kromosom, autis, mutism selektif, keterlambatan fungsional, afasia reseptif dan deprivasi lingkungan. ${ }^{24}$ Faktor penyebab gangguan bicara dapat dirinci sebagai berikut:

${ }^{22}$ AH Markum, Gangguan Perkembangan Berbahasa, Buku Ajar Ilmu Kesehatan Anak, Jilid I. (Jakarta: Balai Penerbit FKUI, 1991), hlm. 56-69.

${ }^{23}$ Mustwkupang, Terapi Wicara, http://mustwkupang.blogspot.com/2012/01/terapi-wicara.html, diakses tanggal 09 Mei 2012, jam 10.21 WIB.

${ }^{24}$ Widodo Judarwanto, Faktor resiko gangguan perkembangan bicara dan bahasa padaanak, lihat di http://speechclinic.wordpress.com/2010/04/24/faktor-resiko-gangguan-perkembangan-bicara-dan-bahasa-padaanak/, diakses tanggal 10 Juni 2012, jam 12.30 WIB. 
1. Faktor Internal. Berbagai faktor internal atau faktor biologis tubuh seperti faktor persepsi, kognisi dan prematuritas dianggap sebagai faktor penyebab keterlambatan bicara pada anak. $^{25}$

a. Persepsi. Kemampuan membedakan informasi yang masuk disebut persepsi. Persepsi berkembang dalam 4 aspek: pertumbuhan, termasuk perkembangan sel saraf dan keseluruhan sistem; stimulasi, berupa masukan dari lingkungan meliputi seluruh aspek sensori, kebiasaan, yang merupakan hasil dari skema yang sering terbentuk. Kebiasaan, habituasi, menjadikan bayi mendapat stimulasi baru yang kemudian akan tersimpan dan selanjutnya dikeluarkan dalam proses belajar bahasa anak. Secara bertahap anak akan mempelajari stimulasi-stimulasi baru mulai dari raba, rasa, penciuman kemudian penglihatan dan pendengaran. ${ }^{26}$ Pada usia balita, kemampuan persepsi auditori mulai terbentuk pada usia 6 atau 12 bulan, dapat memprediksi ukuran kosa kata dan kerumitan pembentukan pada usia 23 bulan. ${ }^{27}$ Telinga sebagai organ sensori auditori berperan penting dalam perkembangan bahasa. Beberapa studi menemukan gangguan pendengaran karena otitis media pada anak akan mengganggu perkembangan bahasa. ${ }^{28}$ Sel saraf bayi baru lahir relatif belum terorganisir dan belum spesifik. Dalam perkembangannya, anak mulai membangun peta auditori dari fonem, pemetaan terbentuk saat fonem terdengar. Pengaruh bahasa ucapan berhubungan langsung terhadap jumlah kata-kata yang didengar anak selama masa awal perkembangan sampai akhir umur pra sekolah.

b. Kognisi. Anak pada usia ini sangat aktif mengatur pengalamannya ke dalam kelompok umum maupun konsep yang lebih besar. Anak belajar mewakilkan, melambangkan ide

${ }^{25}$ H.R Maturana, Biology of Language:...., hlm. 63

${ }^{26}$ Augustyn M, Parker S, Zuckerman B, Developmental and behavioral Pediatrics (2nd ed): Language Delays, (Philadelphia : Lippincott Williams \& Wilkins, 2005).

${ }^{27}$ Soetjiningsih, Gangguan bicara dan bahasa pada anak: Tumbuh kembang anak ( Jakarta: EGC, 1995), hlm. 23

${ }^{28}$ Baron MA, Blum NJ, Speech and language disorders. In: Schwartz MW, ed, Pediatric primary care: a problem oriented approach, (St. Louis: Mosby, 1997), hlm. 845-9. 
dan konsep. Kemampuan ini merupakan kemampuan kognisi dasar untuk pemerolehan bahasa anak. Beberapa teori yang menjelaskan hubungan antara kognisi dan bahasa:

1) Bahasa berdasarkan dan ditentukan oleh pikiran ( $\operatorname{cog}$ nitive determinism).

2) Kualitas pikiran ditentukan oleh bahasa (linguistic determinism).

3) Pada awalnya pikiran memproses bahasa tapi selanjutnya pikiran dipengaruhi oleh bahasa.

4) Bahasa dan pikiran adalah faktor bebas tapi kemampuan yang berkaitan. ${ }^{29}$ Sesuai dengan teori-teori tersebut maka kognisi bertanggung jawab pada pemerolehan bahasa dan pengetahuan kognisi merupakan dasar pemahaman kata.

c. Genetik. Berbagai penelitian menunjukkan, bahwa gangguan bahasa merupakan kecenderungan dalam suatu keluarga yang dapat terjadi sekitar $40 \%$ hingga $70 \%$. Separuh keluarga yang memiliki anak dengan gangguan bahasa, minimal satu dari anggota keluarganya memiliki masalah bahasa. Orang tua dapat berpengaruh karena faktor keturunan sehingga bertanggung jawab terhadap faktor genetik. Mungkin sulit mengetahui berapa banyak transmisi intergenerasi gangguan bahasa tersebut, bisa jadi disebabkan oleh kurangnya dukungan lingkungan terhadap bahasa. ${ }^{30}$

d. Prematuritas. Penyebab khusus berkaitan antara permasalahan periode pre atau perinatal dengan gangguan bicara dan bahasa juga telah dibuktikan. Infeksi selama kehamilan, imaturitas dan berat badan lahir rendah dilaporkan

${ }^{29}$ Wahyu Widhiarso, Pengaruh Bahasa Terhadap Pikiran: Kajian Hipotesis Benyamin Whorf dan Edward Saphir, 2005, hlm. 8-9 diakses dari http://widhiarso,staff.ugm.ac.id files hubungan-antara-bahasa-dan pikiran. pdf pada taggal 8 April 2012 pukul 09.12 WIB.

${ }^{30}$ Pembry, ME, Fisher S, Vargha-Khadem F, Watkins KE, Monaco AP, Localisation of a gene implicated in a severe speech and language disorder (Nature Genetics 1998), hlm. 18. 
mempunyai efek negatif pada perkembangan bicara dan bahasa. $^{31}$

2. Faktor Eksternal (Faktor Lingkungan)

Faktor lingkungan termasuk yang paling menentukan. Faktor lingkungan di mana seorang anak dibesarkan telah lama dikenal sebagai faktor penting yang menentukan perkembangan anak. Banyak anak yang berasal dari daerah yang sosial ekonominya buruk disertai berbagai layanan kesehatan yang tidak memadai, asupan nutrisi yang buruk merupakan keadaan tekanan dan gangguan lingkungan yang mengganggu berbagai pertumbuhan dan perkembangan anak, diantaranya gangguan bahasa. ${ }^{32}$

a. Pola asuh. Law dkk., juga mengemukakan bahwa anak yang menerima contoh berbahasa yang tidak baik dari keluarga, tidak memiliki pasangan komunikasi dan juga kurang memiliki kesempatan untuk berinteraksi akan memiliki kemampuan bahasa yang rendah.

b. Lingkungan verbal. Lingkungan verbal mempengaruhi proses belajar bahasa anak. Anak di lingkungan keluarga profesional akan belajar kata-kata tiga kali lebih banyak dalam seminggu dibandingkan anak yang dibesarkan dalam keluarga dengan kemampuan verbal lebih rendah. ${ }^{33}$

Anak yang terpapar berbagai faktor risiko, memiliki risiko mengalami gangguan perkembangan yang semakin meningkat. Salah satu yang termasuk gangguan perkembangan anak tersebut adalah specific language impairment (SLI). Hal ini telah dilaporkan oleh Spitz dan Tallal Flax, mereka menjelaskan secara umum tentang pencapaian yang buruk dalam berbahasa pada anak meskipun anak tersebut memiliki pendengaran dan intelegensi nonverbal yang normal.

\footnotetext{
${ }^{31}$ Brooks-Gunn. J \& Liaw, F., Cumulative familial risks and low birthweight children's cognitive and behavioral development. (Journal of Clinical Child Psychology, 1994), hlm. 360.

${ }^{32}$ Widodo Judarwanto, Penyebab Gangguan Bicara dan Bahasa, lihat di http://speechclinic.wordpress.com/2009/06/28/penyebab-gangguan-bicara-dan-bahasa-2/, diakses tanggal 24 Juni 2012, jam 11.20 WIB.

${ }^{33}$ Tina L. Stanton-Chapman, Derek A. Chapman, Ann P. Kaiser, Terry B. Hancock, Cumulative Risk and Low-Income Children's Language Development. Topics in Early Childhood Special Education, Vol. 24, No. 4, 2004, hlm. 227-237
} 


\section{Terapi Wicara}

Terapi wicara adalah suatu ilmu yang mempelajari tentang gangguan bahasa, wicara dan suara yang bertujuan untuk digunakan sebagai landasan membuat diagnosis dan penanganan. Dalam perkembangannya terapi wicara memiliki cakupan pengertian yang lebih luas dengan mempelajari hal-hal yang terkait dengan proses berbicara, termasuk di dalamnya adalah proses menelan, gangguan irama/kelancaran dan gangguan neuromotor organ artikulasi (articulation) lainnya.

Terapis wicara adalah seseorang yang telah lulus pendidikan terapi wicara baik di dalam maupun luar negeri sesuai dengan ketentuan peraturan perundang-undangan yang berlaku. (Peraturan MENKES RI No: 867/MENKES/PER/VIII/2004). ${ }^{34}$ Terapis wicara memiliki tugas, tanggung jawab, kewenangan serta memiliki hak secara penuh untuk melaksanakan pelayanan terapi wicara secara profesional di sarana pelayanan kesehatan.

Prosedur kerja terapi wicara secara lebih terperinci diuraikan sebagai berikut: 1) Asesmen, bertujuan untuk mendapatkan data awal sebagai bahan yang harus dikaji dan dianalisa untuk membuat program selanjutnya. Asesmen ini meliputi tiga cara, yaitu melalui anamnesa, observasi, dan melakukan tes, di samping itu juga diperlukan data penunjang lainnya seperti hasil pemeriksaan dari ahli lain. 2) Diagnosis dan prognosis, setelah terkumpul data, selanjutnya data tersebut digunakan sebagai bahan untuk menetapkan diagnosis dan jenis gangguan/gangguan untuk membuat prognosis tentang sejauh mana kemajuan optimal yang bisa dicapai oleh penderita. 3) Perencanaan terapi wicara, perencanaan terapi wicara ini secara umum terdiri dari: (a) Tujuan dan program (jangka panjang, jangka pendek dan harian), (b) Perencanaan metode, teknik, frekuensi dan durasi, (c) Perencanaan penggunaan alat, (d) Perencanaan rujukan (jika diperlukan), (e) Perencanaan evaluasi. 4) Pelaksanaan terapi wicara, pelaksanaan terapi harus mengacu pada tujuan, teknik/metode yang digunakan serta alat dan fasilitas yang digunakan. 5) Evaluasi, kegiatan ini terapis wicara menilai kembali kondisi pasien dengan membandingkan kondisi, setelah diberikan terapi dengan data sebelum diberikan terapi. Hasilnya kemudian digunakan untuk membuat

${ }^{34}$ Ikatwi, Kode Etik Terapi Wicara, http://ikatwipusat.tripod.com/kodeetik.htm, diakses tanggal 08 April 2012, jam 09.55 WIB. 
program selanjutnya. 6) Pelaporan hasil, pelaporan pelaksanaan dari asesmen sampai selesai program terapi dan evaluasi.

\section{Metode ABA}

Metode ABA adalah metode yang terstruktur dan mudah diukur hasilnya, sebagaimana metode ABA. Dengan demikian metode ini dapat dengan mudah di ajarkan kepada para calon pasien terapi. Selain untuk penyandang autisme, metode ABA yang tegas dan tanpa kekerasan ini sangat baik bila diterapkan kepada anak-anak dengan kelainan perilaku lainnya, bahkan anak normal.

Prinsip dasar metode ABA merupakan cara pendekatan dan penyampaian materi kepada anak yang harus dilakukan seperti berikut ini:

1. Kehangatan yang berdasarkan kasih sayang yang tulus, untuk menjaga kontak mata yang lama dan konsisten

2. Tegas (tidak dapat ditawar-tawar anak)

3. Tanpa kekerasan dan tanpa marah

4. Prompt (Bantuan, arahan) secara tegas tapi lembut.

5. Apresiasi anak dengan imbalan yang efektif, sebagai motivasi agar selalu bergairah

Dalam menciptakan suasanan yang kondusif dalam mendidik anak, terapis menggunakan prinsip menciptakan suasana yang penuh kehangatan dan kedamaian. Diusahakan terapis tidak melibatkan emosi marah/jengkel dan kasihan sewaktu mengajar anak. Dengan begitu nantinya dengan sendirinya tidak menyukai kekerasan dalam bersosialisasi dengan yang lain. Selain itu anak akan berkembang menjadi individu yang toleran terhadap perbedaan pendapat dan sekaligus kreatif.

ABA terdiri dari tiga kata. Yaitu Applied yang berarti terapan, Behavior yang berarti perilaku sedangkan Analysis memiliki pengertian: mengurai/memecah menjadi bagian-bagian kecil, mempelajari bagian-bagian tersebut, melakukan dan memodifikasi. Dari tiga kata tersebut ABA dapat diartikan sebagai ilmu terapan yang mengurai, mempelajari dan memodifikasi perilaku. Menurut Sutady:

"Pengertian dari ABA itu sendiri adalah ilmu yang menggunakan prosedur perubahan perilaku, untuk membantu individu 
membangun kemampuan dengan ukuran nilai-nilai yang ada di individu". ${ }^{35}$

Terapi ABA merupakan suatu bentuk modifikasi perilaku melalui pendekatan perilaku secara langsung, dengan lebih memfokuskan pada perubahan secara spesifik. Baik berupa interaksi sosial, bahasa dan perawatan diri sendiri. ${ }^{36}$ Adapun teknik ABA menurut Handojo sebagai berikut:

1. DTT (Discrete Trial Training). Adalah salah satu tehnik utama dari ABA, sehingga kadang ABA disebut juga DTT. Arti harfiah dari DTT adalah latihan uji coba yang jelas/nyata. DTT terdiri dari "siklus" yang dimulai dengan intruksi, prompt, dan di akhiri dengan imbalan.

2. Discrimination Training atau Discriminating. Teknik membedakan ini dipakai untuk melabel atau identifikasi. Tahap kognitif atau kemmapuan reseptif ini digunakan untuk menamai atau mengenal hal-hal seperti huruf, warna, bentuk, tempat, orang dan sebagainya. Untuk meyakinkan bahwa anak benarbenar memahami/mengenali hal secara konsisten, diperlukan pembanding. Apabila anak tetap dapat mengidentifikasi hat tersebut tanpa ragu, maka anak telah benar-benar mengenalnya.

3. Matching atau Mencocokkan. Teknik ini dapat dipakai sebagai pemantap identifikasi maupun sebagai permulaan latihan identifikasi. Mencocokkan dapat dipakai juga untuk melatih ketelitian anak, yaitu dengan memberikan beberapa/banyak hal yang dicocokkan. Menurut terapis wicara, jumlah hal yang dicocokkan jangan lebih dari 25 buah.

4. Fading berarti meluntur. Yang dilunturkan adalah prompt kepada anak. Dari prompt penuh kemudian dikurangi secara bertahap sampai anak berhasil melakukan tanpa prompt lagi.

5. Shaping berarti pembentukan. Teknik ini biasanya dipakai saat mengajarkan kata-kata verbal.

6. Chaining adalah menguraikan perilaku kompleks menjadi beberapa mata rantai perilaku yang paling sederhana. Tiap mata rantai diajarkan tersendiri dengan siklus DTT. Apabila anak menguasai tiap mata rantai, maka diadakan pengga-

35 Sutady Rudi, Autisme dan ABA/Metode Loovas. (Jakarta: Jakarta Medical Center, 2002), hlm. 4

${ }^{36}$ www.putera kembara.com, diakses tanggal 30 Mei 2012, jam 10.23 WIB. 
bungan kembali sehingga menjadi perilaku yang utuh. Teknik ini dipakai sewaktu terapis mengajarkan memasang kaos kaki, melepaskan kaos kaki, memakai baju kaos, melepaskan baju kaos dan sebagainya.

Materi program kurikulum untuk anak berkebutuhan khusus dikelompokkan ke dalam kategori, materi dan aktivitas yang terdiri dari 3 tingkatan yaitu tingkat dasar, tingkat intermediate dan tingkat advanced. Tingkat dasar intermediate dan tingkat advanced. Tingkat dasar dan intermediate terdiri dari enam kategori:

1. Kemampuan mengikuti pelajaran, kepatuhan dan kontak mata adalah kunci masuk ke metode ABA. Tetapi menurut penulis, kedua kemampuan ini adalah kunci setiap kali kita ingin mengajarkan sesuatu kepada anak. Tanpa kedua hal itu mustahil kita dapat mengajarkan sesuatu kepada anak secara efektif.

2. Kemampuan imitasi, Kemampuan menirukan adalah kemampuan perilaku dasar seorang anak. Kemampuan menirukan harus dimiliki oleh seorang anak, maka terapis harus mengajarkannya sejak awal. Kemampuan meniru di mulai dengan latihan motorik kasar, kemudian motorik halus, dan terakhir motorik mulut. Latihan motorik kasar berguna untuk meningkatkan kemampuan fisik anak yang dapat meningkatkan rasa percaya dirinya. Sedangkan motorik halus terutama ditujukan untuk melatih konsentrasi dan koordinasi. Tujuan utama dari latihan motorik halus adalah memampukan anak untuk menulis. Motorik mulut berguna untuk membentuk kemampuan berbicara, di mana akhirnya bertujuan untuk memberikan kemampuan berbahasa yaitu bicara yang dipakai untuk berkomunikasi dengan orang lain. Goal terkhir yang ingin dicapai adalah kemampuan berkomunikasi dua arah.

3. Kemampuan bahasa reseptif (kognitif), Kemampuan bahasa reseptif (kognitif) adalah kemampuan mengenalkan akan beragam benda atau hal. Kemampuan ini disebut juga identifikasi dan dapat berlanjut ke kemampuan melabel, kemudian kemampuan bahasa ekspresif. Bagi anak-anak dengan daya tangkap yang baik, pada saat diajarkan kemampuan bahasa reseptif, dapat langsung dilanjutkan dengan kemampuan ekspresif. Akan tetapi pada anak-anak dengan daya tangkap lemah sebaiknya kedua kemampuan ini diajarkan terpisah. 
4. Kemampuan bahasa ekspresif, Mengajarkan bahasa ekspresif adalah memberikan kemampuan pada anak untuk mengingat hal-hal yang sudah terekam dalam memori untuk diekspresikan. Oleh karena itu kemampuan ini harus diajarkan setelah konsep meniru dan konsep bahasa kognitif sudah cukup dikuasai anak.

5. Kemampuan pre-akademik, Kemampuan Pra-akademik diindikasikan dengan adanya kemampuan mengenal warna, bentuk, angka, huruf, deskripsi orang, tempat, profesi dan lain-lain. Di sini dibutuhkan banyak alat perega, untuk membantu anak menggunakan kemampuan visualnya. Mereka akan lebih mudah mengingatnya. Sebaiknya alat peraga yang digunakan tidak terlalu kecil dan juga jangan terlalu besar. Minimal $6 \times 6 \mathrm{~cm}^{2}$ dan maksimal $8 \times 8 \mathrm{~cm}^{2}$. Oleh karena penggunaannya tidak terlalu lama dan jumlahnya sangat banyak, sebaiknya memakai alat peraga yang semurah mungkin.

6. Kemampuan bantu diri, Kemampuan membantu diri bertujuan untuk memampukan anak hidup mandiri melakukan kegiatan rutin sehari-hari, yaitu makan, minum, mandi, buang ait besar, buang air kecil, memakai dan melepas baju, memakai dan melepas kaos kaki, dan kegiatan-kegiatan rutin lainnya. Untuk melengkapi semuanya ini peranan guru dan orang tua sangat mempercepat kemampuan seorang anak.

Untuk kemampuan advanced ada tiga tambahan kategori yaitu kemapuan sosialisasi dan kemampuan bahasa abstrak serta kesiapan masuk sekolah. Kepatuhan dan kontak mata yang termasuk dalam kategori A merupakan kunci masuk metode Loovas. Tanpa penguasaan kedua kemampuan ini, anak autisma atau gangguan yang lain termasuk terlambat bicara akan sangat sulit sekali diajarkan aktivitas-aktivitas perilaku yang lain. Setelah kedua hal ini dikuasai anak, kemudian dapat dilanjutkan dengan mengajarkan kemampuan bahasa reseptif, bahasa ekspresif, kemampuan pre akademik, kemampuan bantu diri, kemampuan bahasa abstrak dan kemampuan sosialisasi dapat diajarkan secara bertahap dan teratur.

\section{E. Terapi Sensori Integrasi}

Sejarah sensori Integrasi (SI) diterbitkan kepada publik pertama kali tahun 1966 oleh Jean Ayres Phd OTR tentang inter- 
vensi metode SI dan peran OT dalam metode tersebut. Ayres mengembangkan teori Sensori lintegrasi untuk menjelaskan masalah penginterpretasian sensasi dari tubuh dan lingkungan serta kesulitan pada akademik dan motor learning dalam memenuhi tuntutan lingkungan yang mempengaruhi manusia untuk melakukan occupation. ${ }^{37}$ Perlu diketahui bahwa terapi sensori integrasi hanya merupakan sebagian dari pendekatan terapi okupasi. Seorang terapis okupasi berperan dalam mengevaluasi dan memberi terapi, bila seseorang tidak dapat melakukan tugas hariannya dengan baik. Pada anak-anak, okupasi untuk mereka mancakup: kemandirian, kemampuan untuk mengikuti perkembangan anak, dan kemampuan untuk mendapatkan kegembiraan, kepuasan, dan pengembangan diri dari aktivitas bermain dan semua hal tersebut diperhitungkan sesuai dengan umur anak yang bersangkutan. Beberapa pendekatan dalam memberikan terapi okupasi bisa juga disertakan dalam memberikan terapi sensori integrasi pada anak-anak. ${ }^{38}$

Sensori integrasi merupakan proses neurobiologi yang mengacu pada pengintegrasian dan penafsiran stimulus sensori dari lingkungan oleh otak. Sedangkan disfungsi sensori integrasi adalah suatu kekacauan dimana input sensori tidak terintegrasi atau tertata sewajarnya di dalam otak sehingga menimbulkan permasalahan dalam pengembangan, pengolahan informasi serta perilaku. ${ }^{39}$

Sensory Integration Disfunction (SID) adalah proses fungsi kerja otak yang tidak semestinya, dari saat penerimaan input hingga dilanjutkannya ke sistem syaraf perasa untuk diterjemahkan mengalami gangguan. ${ }^{40}$ Disfungsi sensori integrasi terjadi pada sistem susunan saraf pusat di dalam otak, menyebabkan otak tidak mampu melakukan analisis, pengorganisasian, dan tidak mampu melakukan hubungan atau integrasi pesan-pesan sensoris. Akibat ketidakberfungsian integrasi sensoris, seorang anak tidak

${ }^{37}$ Fatur, Occupational Therapi, lihat di http://fatur-occupationaltherapist.blogspot. com/ diakses tanggal 22 Maret 2012, jam 11.45 WIB.

38 Mirza Maulana, Anak Autis: Mendidik Anak Autis dan Gangguan Mental Lain Menuju Anak Cerdas dan Sehat, (Yogyakarta: Katahati, 2007), hlm. 141 .

39 Cindy Hatch, Sensory Integration (http://www.autism.org/si.html), Akses: 1 April 2012.

${ }^{40}$ Yehosua, dkk., "Terapi Sensori Integrasi, Okupasi dan Wicara untuk Mengoptimalkan Kemampuan Anak Autis” ( Makalah seminar, Semarang: P2GPA, 2002), hlm. 30. 
dapat melakukan respon atau menanggapi informasi sensoris untuk dijadikan sesuatu yang bermakna secara konsisten. Anak tersebut memperoleh kesulitan dalam menggunakan informasi sensoris untuk dibuat rencana atau diorganisasi dengan apa yang semestinya ia lakukan. Jadi, tidak belajar secara mudah. ${ }^{41}$

Sensori integrasi terpusat di tiga dasar yaitu tactile, vestibular dan proprioceptive, ketiganya terbentuk dan terhubung sebelum seseorang dilahirkan dan akan terus berkembang ketika seseorang berinteraksi dengan lingkungannya. Tactile, vestibular dan proprioceptive tidak hanya saling berhubungan, tetapi juga terhubung dengan sistem lain di dalam otak, sistem yang saling terhubung ini akan membantu seseorang untuk survive, dan proses timbal baliknya akan dapat menginterpretasikan dan bereaksi terhadap stimulus yang datang dari tubuh dan lingkungan. ${ }^{42}$ Sensori integrasi membantu secara memadai proses sensorik seorang anak agar tercapai: kemampuan dalam mengolah informasi secara tepat, kemampuan dalam berkonsentrasi, kemampuan organisasi, selfesteem, kemampuan kontrol diri, percaya diri, kemampuan akademis, kemampuan berpikir abstrak, kemampuan spesialisasi dari masing-masing sisi tubuh dan otak. ${ }^{43}$

Sensori integrasi disini dapat diartikan sebagai proses kerja otak yang tidak semestinya dalam mengolah informasi dan menginterpretasikannya sehingga tidak dapat memberikan respon yang sesuai. Sistem yang ada pada sensori integrasi meliputi:

1. Sistem Vestibular (Keseimbangan)

Sistem vestibular terletak pada bagian dalam telinga dan berfungsi mendeteksi gerakan dan perubahan-perubahan yang terjadi pada posisi kepala, apakah tegak lurus atau dimiringkan, dan kelainan pada sistem ini terwujud dalam dua cara yang berbeda, beberapa anak hipersensitif terhadap rangsangan vestibular dan bereaksi berlebihan terhadap aktivitas gerakan yang biasa. Sebagian yang lain berperilaku undersensitif, sehingga seringkali mereka menunjukkan perilaku yang berlebih seperti melompat dan memutar tubuh.

${ }^{41}$ Bandi Delphie, Pendidikan Anak Autis, (Yogyakarta: Intan Sejati, 2009), hlm. 49-50.

${ }^{42}$ Cindy Hatch, Sensory Integration (http://www.autism.org/si.html), Akses: 1 April 2012.

${ }^{43}$ Anonimous, Terapi Okupasi (http://www.saranaku.com), Akses: 22 Februari 2006. 
Vestibular sense adalah indera yang memproses informasi tentang pergerakan (movement), gaya berat (gravitasi), keseimbangan (balance) yang diterima melalui telinga. ${ }^{44}$ Dan memberi info tentang aktivitas yang berhubungan grafitasi (seperti ketika berputar, melompat, naik atau turun, berayun), pergerakan dan mempertahankan posisi berdiri, seberapa cepat dan arah serta ketika seseorang berada dalam ruang. Sistem vestibular berfungsi untuk: mempertahankan tonus otot dan postur sehingga bila ada yang bergerak maka posisi tubuh akan mendukung, membantu mempertahankan visul field secara stabil oleh mata dan otot leher untuk mengkompensasi gerakan kepala dan tubuh, dapat melakukan aktivitas dengan menggunakan ke-2 sisi tubuh secara bersamaan, memacu cara belajar yang lebih baik. ${ }^{45}$ Gejala dari gangguan vestibular bisa terwujud dalam bentuk perilaku-perilaku, dan kemungkinan anak memiliki satu atau beberapa dari ciri perilaku di bawah ini:

a. Sistem vestibular juga berfungsi untuk memberikan keseimbangan pada tubuh, anak dengan gangguan pada keseimbangan menunjukkan perilaku sebagai berikut: mudah jatuh atau hilangnya keseimbangan ketika memanjat tangga, mengendarai sepeda, melompat, berdiri dengan satu kaki, dan ketika menutup kedua matanya, bergerak dengan tidak teratur, canggung, kaku dan gelisah. ${ }^{46}$

b. Anak yang mengalami gangguan vestibular akan menunjukkan sikap tubuh yang lemah dan tidak berdaya, hal ini dikarenakan tonus otot yang lemah, sehingga menunjukkan perilaku-perilaku sebagai berikut: tubuh kendur dan lemas, terasa lemas atau lesu saat diangkat, merasa pincang ketika berjalan, membantu keseimbangan tubuh ketika berjalan dengan cara berjalan terhuyunghuyung, cenderung untuk merosot ketika duduk, lebih suka berbaring dari pada duduk, dan terus menerus menyandarkan kepalanya pada salah satu tangannya, duduk di lantai dengan posisi "W", yaitu lutut-lututnya bengkok dan kakinya memperluas ke luar sisi-sisinya, saat

\footnotetext{
${ }^{44}$ Yehosua, dkk., Terapi Sensori Integrasi ..., hlm. 40

${ }^{45}$ Yehosua, dkk., Terapi Sensori Integrasi ..., hlm. 46

${ }^{46}$ Yehosua, dkk., Terapi Sensori Integrasi ..., hlm. 46
} 
tengkurap sulit menegakkan kepala, kaki, mempunyai kesukaran memutar tombol pintu atau sesuatu yang memerlukan tekanan, genggamannya mudah lepas ketika memegang pensil, gunting, atau sendok, menggenggam dengan sangat suatu benda karena takut untuk melepaskannya, mempunyai masalah dengan pencernaan, seperti kurang bisa mengendalikan kandung kemihnya, mudah lelah pada aktivitas-aktivitas fisik. ${ }^{47}$

\section{Sistem Proprioceptive}

Proprioceptive adalah sistem yang mengacu pada komponen-komponen dari otot, sendi, dan urat daging yang memberikan kesadaran pada seseorang tentang posisi tubuhnya. Proprioceptive yang berfungsi efisien maka posisi tubuh secara otomatis akan disesuaikan dengan situasisituasi yang berbeda, serta kemampuan untuk merencanakan tugas-tugas motorik yang berbeda.

Proprioceptive sense adalah indera yang memproses informasi tentang posisi tubuh, bagian tubuh yang diterima oleh otot-otot, persendian, tulang. ${ }^{48}$ Gangguan proprioceptive menunjukkan, bahwa proses dari otak ke otot dan persendian tidak dapat tersalurkan dengan baik. Contoh: anak melihat mainan, tetapi ketika memegangnya anak merasa kesulitan, atau ketika memegang pensil anak tidak dapat mengontrol penekanan dari tulisan yang ingin dibuatnya, sehingga menolak untuk menulis. ${ }^{49}$

Gejala dari gangguan proprioceptive bisa terwujud dalam bentuk perilaku-perilaku, dan kemungkinan anak memiliki satu atau beberapa dari ciri perilaku di bawah ini: 1) Anak dengan gangguan disfungsi sensori akan menampakkan perilaku-perilaku sebagai berikut: dengan sengaja menubruk atau membentur atau menjatuhkan atau merobohkan bendabenda di sekelilingnya; 2) Interaksi proprioceptive dengan bagian-bagian otak dapat menyebabkan anak bisa melakukan gerakan yang terkoordinir secara baik, gangguan pada interaksi proprioceptive mengakibatkan terganggunya kesadaran tubuh, motor planning dan motor control; 3) Gangguan pada proprioceptive juga menyebabkan anak melakukan gerakan-

\footnotetext{
${ }^{47}$ Yehosua, dkk., Terapi Sensori Integrasi ..., hlm. 48-51

${ }^{48}$ Yehosua, dkk., "Terapi Sensori Integrasi,...hlm. 40

${ }^{49}$ Yehosua, dkk., Terapi Sensori Integrasi ..., hlm. 29
} 
gerakan yang tidak efisien; 4) Gangguan proprioceptive akan dapat mempengaruhi postur tubuh, sehingga anak akan memiliki ketidakstabilan postur tubuh; 5) Selain dalam bentuk perilaku gangguan proprioceptive juga dapat mempengaruhi emosi anak. ${ }^{50}$

\section{Sistem Tactile}

Tactile sense adalah indera yang memproses informasi tentang perasa dan peraba yang diterima melalui kulit. ${ }^{51}$ Gangguan pada sistem tactile menunjukkan bahwa stimulus yang datang dari reseptor kulit tidak terproses dengan baik. ${ }^{52}$

Sistem tactile adalah sistem yang menginformasikan kepada otak tentang kegelisahan yang dirasakan di bawah permukaan kulit, informasi ini termasuk sentuhan ringan, nyeri, temperatur dan tekanan. Gangguan pada sistem ini berupa kesalahan persepsi terhadap sentuhan dan rasa nyeri, mengasingkan diri, mudah, marah, dan hiperaktif. ${ }^{53}$ Gejala dari gangguan Tactile dapat menyebabkan reaksi perilaku yang beragam, dan kemungkinan anak akan mengalami beberapa gejala perilaku menunjukkan tidak suka makanan karena bentuknya, tidak suka sikat gigi, menggunakan pasta gigi, tidak menyukai mukanya dibasuh, reaksi berbeda-beda saat potong rambut, sisir rambut, mencuci tangan, dan menggunakan shower, takut untuk merangkak atau berjalan, selalu berusaha untuk menyelimuti tubuhnya, kurang peka terhadap suhu, tidak mau berpakaian, tidak menyukai tekstur pakaian tertentu, label baju, seprei, tidak menyukai sentuhan fisik, khususnya sentuhan kuat, menjadi agresif secara lisan atau fisik bila sentuhan dirasa menjadi ancaman, tidak menyukai keramaian, berjalan di baris paling belakang, menolak untuk bermain pasir, melukis dengan jari.

4. Sistem Visual

Menurut Kranowitz sistem visual adalah sebuah proses yang sangat kompleks yang memungkinkan kita untuk mengidentifikasi apa yang dilihat, untuk mengantisipasi apa yang datang ke kita, dan mempersiapkan kita dalam

\footnotetext{
${ }^{50}$ Yehosua, dkk., Terapi Sensori Integrasi ..., hlm. 54-55.

${ }^{51}$ Yehosua, dkk., Terapi Sensori Integrasi ..., hlm. 40.

${ }^{52}$ Yehosua, dkk., Terapi Sensori Integrasi ..., hlm. 29.

${ }^{53}$ Yehosua, dkk., Terapi Sensori Integrasi ..., hlm. 57.
} 
menghadapi sesuatu. ${ }^{54}$ Kemampuan persepsi visual adalah kemampuan untuk mengenali hubungan seseorang dalam suatu ruang dengan benda dan dirinya, membedakan suatu objek dengan yang lainnya, membedakan suatau objek dengan latar belakang, mengenali secara tepat ketika diperlihatkan bagian dari sebuah benda secara sekilas, serta kemampuan untuk mengingat secara tepat dan berurutan dari beberapa item. $^{55}$

Gejala dari gangguan visual ditunjukkan dengan perilaku sebagai berikut: sering menabrak sesuatu, merasa selalu terhimpit atau kurang ruang, tidak mampu untuk mengatur barang miliknya atau tugasnya (tidak bisa mengerjakan tugasnya sampai selesai), sulit untuk tetap dalam aturan, sulit untuk melakukan kontak mata, sulit untuk mengerti tanda (simbol), tulisan tangan yang kurang baik, menghindari untuk membaca, menulis, menggambar, mengalami kesulitan dalam membangun, menyusun balok dan mengerjakan puzzle, cepat lelah, sulit untuk mengenali dan menulis huruf, angka, bentuk, mengalami kesulitan untuk mengikuti gerak benda dengan mata, memiliki keseimbangan tubuh yang kurang baik. ${ }^{56}$

\section{Sistem Auditori}

Menurut Kranowitz (dalam Nisrina) dijelaskan bahwa sistem auditori adalah kemampuan untuk mendengar sesuatu atau suara. Kita lahir dengan kemampuan ini, kita tidak bisa belajar bagaimana cara melakukan sesuatu tanpa kita mendengarnya. ${ }^{57}$

Proses auditori bertugas untuk menerima informasi, merasakan dan membedakan antar suara, mengumpulkan dan menguraikan suara, mengingat apa yang didengar, mengintegrasikan apa yang didengar dan mengekspresikannya men-

${ }^{54}$ Dalam Nisrina Khamida, "Studi Deskriptif Tentang Penerapan Terapi Sensori Integrasi Pada Anak Dengan Gangguan Spektrum Autistik (GSA) di Pusat Terapi Perilaku 'A-Plus' Malang” (Skripsi, Fakultas Psikologi: UIN Malang, 2005), 36.

${ }^{55}$ Yehosua, dkk., Terapi Sensori Integrasi ...,hlm. 15.

${ }^{56}$ Yehosua, dkk., Terapi Sensori Integrasi ..., hlm. 16-17.

${ }^{57}$ Taufiq Pasiak, Revolusi IQ/EQ/SQ: Antara Neurosains dan al-Qurán (Bandung: Mizan, 2002), hlm. 41. 
jadi sebuah respon, menentukan asal suara. ${ }^{58}$ Gejala dari gangguan auditori ditunjukkan dengan perilaku: kesulitan dalam pembentukan kata pronound, kesulitan dalam preposisi, salah pendengaran, sulit fokus untuk mendengarkan suara yang ditujukan padanya ketika ada suara latar belakang yang sama sekali tidak berkaitan, menjadi hiper atau hipo terhadap suara yang didengar, mudah merasa bingung, mempunyai kesulitan untuk mengurutkan bahasa, membutuhkan perhatian ekstra untuk dapat berkonsentrasi dan melakukan tugas, perhatian kurang baik dan cepat lupa.

\section{F. Penutup}

Pendidikan adalah hak asasi yang paling mendasar bagi setiap manusia, tidak terkecuali bagi anak luar biasa atau anak berkebutuhan khusus. Dalam Undang-Undang Dasar 1945 pasal 31 ayat 2 disebutkan bahwa "tiap-tiap warga Negara berhak mendapatkan pengajaran", dan ditambahkan dalam UndangUndang nomor 20 tahun 2003 tentang Sistem Pendidikan Nasional pasal 5 ayat 2 bahwa "Negara yang memiliki kelainan fisik, emosional, mental, intelektual, atau sosial berhak memperoleh pendidikan khusus". Dengan demikian berarti anak-anak yang dengan kebutuhan khusus seperti, tunanetra, tunarungu, tunagrahita, tunadaksa, tunalaras dan anak-anak berkesulitan belajar juga memiliki kesempatan yang sama untuk mendapatkan pendidikan.

\section{Kepustakaan}

AH Markum, 1991, Gangguan perkembangan berbahasa, Dalam: Markum, Ismael S, Alatas H, Akib A, Firmansyah A, Sastroasmoro S, editor, Buku ajar ilmu kesehatan anak, Jilid I. Jakarta: Balai Penerbit FKUI.

Augustyn M, Parker S, Zuckerman B, 2005, Developmental and behavioral Pediatrics (2nd ed):Language Delays, Philadelphia: Lippincott Williams \& Wilkins.

${ }^{58}$ Danah Zohar \& Ian Marshall, SQ: Memanfaatkan Kecerdasan Spiritual dalam Berpikir Integralistik dan Holistik untuk Memaknai Kehidupan (terj.) Rahmani Astuti (Bandung: Mizan,2002), hlm. 35-36. 
Blum NJ, Baron MA, 1997, Speech and language disorders. In: Schwartz MW, ed, Pediatric primary care: a problem oriented approach, St. Louis: Mosby.

Danah Zohar \& Ian Marshall, 2002, SQ: Memanfaatkan Kecerdasan Spiritual dalam Berpikir Integralistik dan Holistik untuk Memaknai Kehidupan (terj.) Rahmani Astuti, Bandung: Mizan.

Delphie, Bandi, 2009, Pendidikan Anak Autis, Yogyakarta: Intan Sejati.

HAllahan dkk, Daniel P, 2009, Exceptional Learners: An Introduction to Special Education, Boston: Pearson Education Inc.

Hatch, Cindy, Sensory Integration (http://www.autism.org/si.html), Akses: 1 April 2012.

Hurlock, Elizabeth B., 2008, Perkembangan Anak, edisi keenam, McGraw-Hill: Erlangga.

IG. Ranuh, 2002, Tumbuh Kembang Anak dan Remaja, Jakarta: Sagung Seto.

Ikatwi, Kode Etik Terapi Wicara, http://ikatwipusat.tripod.com/kodeetik.htm, diakses tanggal 08 April 2012, jam 09.55 WIB.

Judarwanto, Widodo, Faktor resiko gangguan perkembangan bicara dan bahasa padaanak, lihat di http://speechclinic.wordpress.com/2010/04/24/faktor-resiko-gangguanperkembangan-bicara-dan-bahasa-pada-anak/, diakses tanggal 10 Juni 2012, jam 12.30 WIB.

-----, Keterlambatan bicara - Speech delay. www.keterlambatanbicara.blogspot.com. 2008, Diakses pada tanggal 14 maret 2012 jam 10.45 WIB.

-----, Penyebab Gangguan Bicara dan Bahasa, lihat di http://speechclinic.wordpress.com/2009/06/28/penyebabgangguan-bicara-dan-bahasa-2/, diakses tanggal 24 Juni 2012, jam 11.20 WIB.

Liaw, F \& Brooks-Gunn. J., 1994, Cumulative familial risks and low birthweight children's cognitive and behavioral development. Journal of Clinical Child Psychology

Mansur, 2009, Pendidikan Anak Usia Dini Dalam Islam, Yogyakarta: Pustaka Pelajar. 
Marimba, Ahmad D., 1996, Pengantar Filsafat Pendidikan Islam, Bandung: Al-Bayan.

Maulana, Mirza, 2007, Anak Autis: Mendidik Anak Autis dan Gangguan Mental Lain Menuju Anak Cerdas dan Sehat, Yogyakarta: Katahati.

Mudlofir, Ali, Kurikulum Berbasis Kompetensi Tahun 2004 Bidang Studi PAI: Implementasi Mustwkupang, Terapi Wicara, http://mustwkupang.blogspot.com/2012/01/terapiwicara.html, diakses tanggal 09 Mei 2012, jam 10.21 WIB.

Pasiak, Taufiq, 2002, Revolusi IQ/EQ/SQ: Antara Neurosains dan Al-Qurán, Bandung: Mizan.

Terry B. Hancock, Tina L. Stanton-Chapman, Derek A. Chapman, Ann P. Kaiser, 2004, Cumulative Risk and Low-Income Children's Language Development. Topics in Early Childhood Special Education, Vol. 24, No. 4.

Undang-Undang No. 20 tahun 2003, tentang Sistem Pendidikan Nasional dan Penjelasannya, Jakarta: Depdiknas.

Widhiarso, Wahyu, Pengaruh Bahasa Terhadap Pikiran: Kajian Hipotesis Benyamin Whorf dan Edward Saphir, 2005, diakses dari http://widhiarso,staff.ugm.ac.id files hubungan-antarabahasa-dan pikiran.pdf pada taggal 8 April 2012 pukul 09.12 WIB.

www.putera kembara.com, diakses tanggal 30 Mei 2012, jam $10.23 \mathrm{WIB}$

Y. Handoyo, 2009, Autisme pada anak: Menyiapkan Anak Autis untuk Mandiri dan Masuk Sekolah Reguler dengan Metode ABA Basic, Jakarta: Bhuana Ilmu Populer.

Yehosua, dkk., 2002, "Terapi Sensori Integrasi, Okupasi dan Wicara untuk Mengoptimalkan Kemampuan Anak Autis" Makalah seminar, Semarang: P2GPA. 
